Published by Nature and Culture, 8(2), Summer 2013: 205-225.

Berghahn Journals

doi: $10.3167 /$ nc.2013.080205

\title{
Converting community knowledge into catchment nutrient limits: a contructivist analysis of a New Zealand collaborative approach to water management
}

\author{
Ronlyn Duncan \\ Lecturer in Water Management \\ Lincoln University \\ PO Box 84 \\ Lincoln, Canterbury, 7647 \\ New Zealand \\ Tel: +64 34230427 \\ Email: Ronlyn.Duncan@lincoln.ac.nz
}

The question posed in this paper is how shifts in governance ushered in by the sustainability paradigm are reshaping knowledge governance. Drawing on constructivist theories of knowledge, I examine the tension between the sustainability mandate to open up knowledgemaking to local knowledge, and conventional science policy practice that would see it excluded. I present a water management case study from New Zealand's South Island region of Canterbury, where communities are involved in establishing catchment nutrient limits to manage land use and water quality. It is concluded that although local knowledge was embraced within the knowledge-making process, the pursuit of epistemic authority led to its recalibration, aggregation and standardization. As such it was stripped of its complexity. This research highlights the role of politics in anchoring the linear knowledge governance model in place and the challenge for supplanting it.

Key words:

water management, science policy, nutrient limits, knowledge governance, New Zealand, collaborative governance 


\section{Introduction}

In natural resource management decision-making, the relationship between science and policy is conventionally portrayed as a linear one-way process whereby the facts of a matter are sourced from science and subsequently applied to a given policy problem (Irwin and Wynne 1996; Jasanoff 1987, 1990; Pielke 2007). From the constructivist theoretical perspective of this paper, the 'science in-policy out' knowledge governance model disingenuously demarcates science from policy, and casts the former as the authoritative provider of objective knowledge and the latter as the sole realm of values. As such, it constitutes science as providing policy-makers with access to supposedly "autonomous knowledge and independent morality” (Latour 2004: 4), and as showhow detached from politics. The representation of this segregation underpins the credibility and legitimacy of science as well as the policy decisions represented as derived therefrom (Gieryn 1983, 1999; Irwin and Wynne 1996; Jasanoff 1987, 1990).

The question I pose in this paper is how are shifts in governance ushered in by the sustainability paradigm reshaping this conventional linear model of knowledge governance? This is an important question to ask in the context of the sustainability paradigm now embodied in legislation across Western democracies. With a mandate for the simultaneous delivery of social, ecological, cultural and economic values and resource uses, the move to collaboration is seeking not only the involvement of communities in policy-making, but increasingly the embrace of local knowledge alongside that of science (Folke et al. 2005; Scholz and Stiftel 2005; Weber et al. 2010). For example, Weber et al. (2010: 236) maintain that:

There is general agreement that traditional top-down, one-way (from scientists to others), and linear models for conceptualizing the role of science and scientists in 
the policy process are not capable of capturing the changed political, social, and "scientific" realities of the contemporary context for policymaking.

These authors argue that emerging knowledge governance models need to "force science to share the stage with other kinds of knowledge that are grounded in experiential and cultural understandings of problems” (Weber et al. 2010: 283).

Notwithstanding the ongoing work in this direction (see Cash et al. 2006; Lane et al. 2011; Landstrom et al. 2011; Voinov and Bousquet 2010; Wallington et al. 2010; Weber et al. 2010; Whatmore 2009), in contentious natural resource decision-making settings, integrating scientific with local knowledge represents a profound a shift in knowledge governance. It constitutes as authoritative and reliable both scientific and local knowledges. In subscribing to the linear model, as scientists and policy-makers across natural resource management generally do, the involvement of local knowledge would be expected to inject values in knowledge- and policy-making where they have conventionally been deemed not to exist. Hence, such moves are likely to be resisted by scientists and policy-makers given the potential to challenge existing accommodations that have historically engendered their legitimacy and credibility. There are two potentially colliding trajectories here - the sustainability mandate that seeks to open up knowledge-making to local knowledge, and conventional science policy knowledge practice that is likely to see it excluded. The aim of this paper is to examine this tension.

To do so I present a collaborative water management case study from New Zealand that has involved community stakeholder groups in a knowledge production process to set catchment scale nutrient limits to manage the cumulative effects of land use on water quality. The paper proceeds first by presenting a conceptual analytic framework that draws constructivist theoretical insight from the field of Science and Technology Studies (STS). Next, I briefly describe the New Zealand geographic, economic and political context to explain why setting 
nutrient limits is now being pursued in New Zealand. I then present the empirical component of this research which moves to the sub-regional scale and a common representation of the limit setting regime (Figure 1). Drawing on Figure 1, a review of public documents, discussions, and observations, I explain how limit setting was conceived, how local knowledge was sought and, thus, how it was incorporated and converted into catchment nutrient load limits. Drawing on STS theory I then evaluate the empirical material by contrasting two perspectives, one from an epistemological commitment to the linear model and the other as a critique from a contructivist perspective. I illustrate the extent to which the former constitutes knowledge as merely instrumental and its epistemic implications. I consider, too, the implications of the underlying political imperative to uphold epistemic authority on the structure of the limit setting process and how local knowledge was accommodated and translated. It is concluded that in the context of the politics that continue to frame New Zealand's limit setting regime, and the pursuit of epistemic authority, local knowledge was stripped of its complexity. Moreover, its contribution provided science policy actors with a pillar of credibility and legitimacy additional to that of the institution of science. These findings highlight the role of politics in anchoring firmly in place an adherence to the linear model and the depth of the challenge to supplant it.

\section{A constructivist analytic framework}

The science policy nexus has been an important site for constructivist policy analysis from the field of STS over the past several decades. For example, from analysing the wrangling over regulations to control potentially hazardous chemicals in the United States in the 1980s,

Shiela Jasanoff has argued that demarcations between science and policy are a product of “boundary-defining language” (1987: 195; Gieryn 1983, 1999). Jasanoff (1987, 1990) concluded that decisions represented as scientific (and thereby authoritative) by the Environmental Protection Agency were readily challengable by industry and environmental 
groups. Under judicial review they were able to reveal and draw into question the values and contingent judgments that underpinned the regulator's putatively scientific procedures, interpretations and extrapolations of animal studies to human health exposure thresholds.

In general, Jasanoff illustrates that the boundaries erected between science and policy are contestable, negotiable and movable (1987, 1990; Gieryn 1983; 1999), and that discursive delineations that mark out where facts and values begin and end can be used flexibly to delegate power and pursue partisan interests. Therefore, beyond the politically useful representation of a demarcation between science and policy in contentious debates, Jasanoff shows that this connection is far more intertwined (1990, 2004). From the perspective of what Jasanoff (2004) refers to as co-production, facts and values (or nature and culture) are inextricably entangled, and conceptions of their separation are artifacts to be scrutinised rather than something to be taken as real or pre-existing (Jasanoff 2004; Latour 1993).

As a critique of the persistent subject/object binaries, Jasanoff maintains that co-production is "shorthand for the proposition that the ways in which we know and represent the world (both nature and society) are inseparable from the ways in which we choose to live in it” (2004: 3). As such, knowledge-making simultaneously creates “natural and social orders” (Jasanoff 2004: 2-3) or, to put it another way, in our practices of “ordering knowledge”, we are simultaneously "ordering society” (2004: 13). The implication of this theoretical proposition is that knowledge-making is far more than merely an instrumental input to policy-making that it is conventionally deemed to be by adherents to the linear model. Rather, it constitutes and reconfigures nature culture relations. Therefore, the co-production analytic framework can assist evaluating how the shift to embracing local knowledge has reshaped conventional science policy knowledge practice. It can do so by examining not only the discursive delineations that mark off nature from culture but also the intermingling that they obscure. 
Insights drawn from this analysis can contribute to broader understandings of how science and politics interact in practice in the context of sustainability.

\section{A New Zealand water management case study}

This case study examines knowledge-making in the implementation of a collaborative water governance process in New Zealand's South Island region of Canterbury, known as the Canterbury Water Management Strategy (CWMS) (CWMS 2010). The aim of the CWMS is for "[w]ater management solutions to achieve economic, cultural, social and environmental outcomes, together" (Whitehouse 2010: np). Otherwise known as parallel development, and inspired by northern hemisphere ecological modernisation, the ideology to simultaneously pursue increased agricultural production (with augmented irrigation and water storage) and environmental protection, is shared by the current central government which has set a path for instituting pricing instruments to reconcile sustainability objectives (CWMS 2010; Land and Water Forum 2010, 2012; New Zealand National Party 2012). These politics frame New Zealand's limit setting regime.

To establish limits, a key target under the CWMS, a science policy body known as the Land Use and Water Quality Project (LU\&WQP) has involved groups of community stakeholders in a deliberative knowledge production process to establish catchment nutrient load limits for the loss of nitrogen and phosphorus from land use. The CWMS mandates the setting of such limits across the region's ten geographic zones. The first region to undertake the limit setting process was the Hurunui Waiau zone in the north of Canterbury. What occurred in this zone during 2010 provide the empirical resources for this study. For a review of the broader CWMS context for this zone and a discussion of how the LU\&WQP outcomes on limits moved through the CWMS and statutory planning processes, see Memon et al. (2012).

\section{The New Zealand geographic, economic and political context}


The agricultural region of Canterbury, in the middle of New Zealand's South Island, extends from expansive foothills on the eastern side of its Southern Alps to the Pacific Ocean. The Canterbury Plains receive relatively low rainfall, yet precipitation (including snow melt) gathered in the mountains and foothills traverses the landscape to the sea through lakes, porous soils and aquifers at varying depths, hill-fed rivers, meandering spring-fed streams, and wide seasonally cloudy-blue braided rivers. Access to ostensibly abundant freshwater from rivers as well as groundwater has been pivotal in the expansion of agriculture in Canterbury where 70 per cent of New Zealand's irrigated land is situated (CWMS 2010).

New Zealand's society, economy and ecology are inextricably linked. A major proportion of the country’s export income is derived from its primary sector. For example, in 2011, total agriculture, seafood and forestry revenue constituted 71 per cent of the country's total merchandise export income (MAF 2011). Importantly, as at 2010, 30 per cent of total export income was earned from the dairy sector (MAF 2011). As production and export revenues have increased, however, so too has nutrient pollution, in particular excess nitrogen and phosphorus from fertilisers applied to grass for animal feed, from cow urine or dairy shed effluent applied to land that seasonally run off from land into waterways and groundwater. Pathogens from livestock and sediments from land use change also contribute to the agricultural sector's diminishment of water quality (PCE 2012).

There is a growing realisation that the cumulative effects of diffuse non-point source pollution, while not confined to New Zealand, has the potential to undermine the country's clean green, ' $100 \%$ Pure', brand from which a considerable economic bounty is attained. There is concern that the country's long-term economic sustainability (and central government plans to intensify agriculture), could be jeopardised if meaningful action is not taken to clean up in catchments dominated by agricultural land use where excess nutrients, 
sediments and pathogens are enriching and contaminating surface and ground freshwater resources (MfE 2011a; Land and Water Forum 2010, 2012; PCE 2012). While some responses to improving water quality have been significant in respect of high profile and culturally significant water bodies, in general, action on water quality has been characterised as reactive, fragmented and inadequate (PCE 2012; Russell et al. 2011). This situation changed somewhat in 2011 when central government passed its National Policy Statement for Freshwater Management (NPSFM) (MfE 2011b; MfE 2011c) which sets long-awaited national direction for the management of freshwater. Importantly, it requires regional councils to set quantified and enforceable limits for water allocation and water quality. The Canterbury region's CWMS, which also seeks to set limits, sees the Environment Canterbury Regional Council (ECRC) moving not only on the new NPSFM regime, but also setting a precedent for its implementation across New Zealand.

\section{Embracing local knowledge}

The LU\&WQP was established by the regional council to help implement the CWMS. Foreshadowing the intermingling of knowledge and politics across the LU\&WQP, its governance group comprises representatives from the regional council and central government; the dairy sector research institute; dairy, horticulture and arable land industry groups; Fonterra (New Zealand's home grown dairy co-operative that has become the world's largest dairy exporter); indigenous community representatives; government and nongovernment environment groups; a farmer, and representatives from Lincoln University and the National Institute for Water and Atmospheric Research (NIWA), a crown research institute (ECRC 2012). 
With the explicit intention to draw on the local knowledge of the community, the LU\&WQP maintains that "[s]trong community participation ... is important as it will bring local knowledge and experience, as well as providing input and discussion on the practical application of any preferred approach options” (ECRC, no date, np). Similarly, a key LU\&WQP scientific research institution maintains that a crucial aspect of setting limits is the involvement of both biophysical and social scientists, community stakeholders, lawyers and economists (Norton et al. 2010). Another key LU\&WQP research institution maintains that "science centric management alone will not be enough to address these [water quality] issues” (Wedderburn et al. 2011: 25). The sentiments expressed by Weber et al. (2010), that moves to collaborative governance require a change in knowledge governance, are evident here.

\section{The limit setting process structure}

I now outline the structure of the limit setting process as depicted by the LU\&WQP and its contributors. I will then outline how community local knowledge was incorporated into the limit setting process. The accounts on these aspects are drawn from public documents written by the regional council and LU\&WQP contributors as well as clarification discussions around these documents undertaken with LU\&WQP scientists and policy-makers. They are also informed by observations of the second LU\&WQP community process to set nutrient limits which is occurring in the Selwyn Waihora zone, which replicates and extends what occurred in the Hurunui-Waiau zone.

Figure 1 is a representation of the limit setting process that has been and continues to be used by LU\&WQP contributors, the regional council and central government in their presentations and reports on implementing the CWMS, the LU\&WQP and the NPSFM (for example, ECRC 2012: 6; MfE 2011c: 16). 


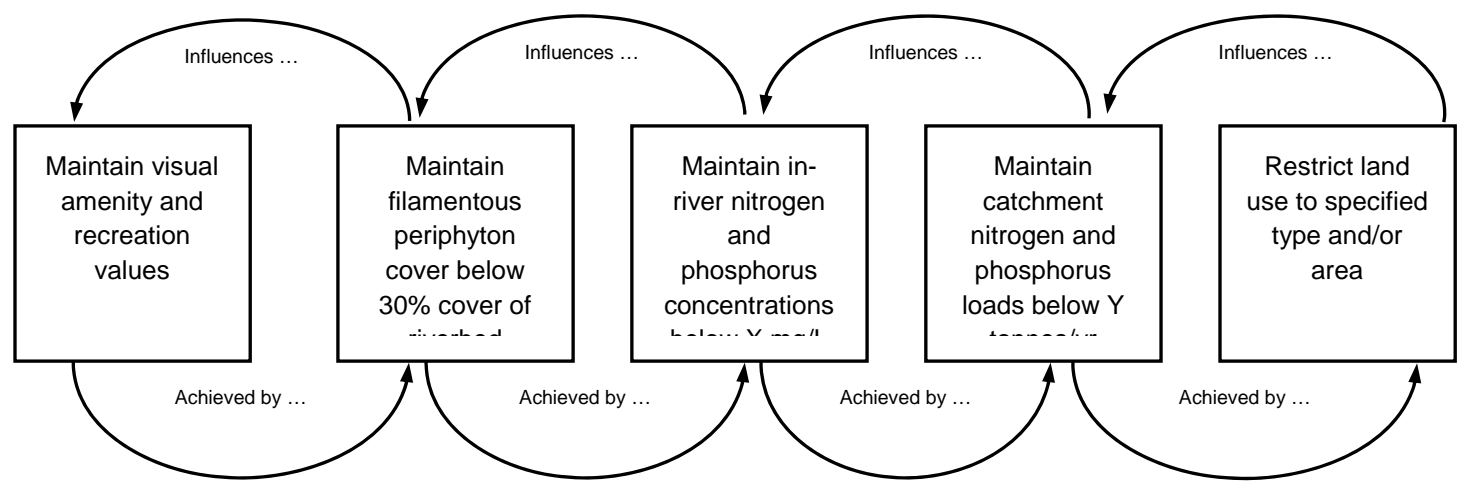

Figure 1: A common representation of New Zealand's limit setting regime (ECRC 2012: 6).

From left to right, the first box represents broadly defined water quality management objectives that represent the starting point of the limit setting process. The second box from the left represents a protection level. It is at this stage that community stakeholders were involved, and their local knowledge sought, to determine an acceptable level of ecological protection. In effect, community stakeholder groups made decisions on how much ecological protection each group was willing to live with (or trade off) to attain a desired level of agricultural expansion. Using ecosystem modelling, a decision on this score was translated into a numeric ecological objective to calculate concentration levels that could be measured and monitored, in this case in terms of the per cent cover of a water body with periphyton (i.e. algae). For example, in a model a specified protection level can be linked to a given level of agricultural production on the basis of the latter's nutrient losses and their uptake in the growth of algae. Therefore, 50 per cent periphyton cover would represent more agricultural production, more nutrient losses, more algal growth and less ecological protection, while ten per cent would equate to less agricultural production, less nutrient loss, less algal growth and a higher level of ecological protection (Norton and Kelly 2010: 6). In effect, this is where a 'balance' was struck across the sustainability objectives by the 
community. The middle box represents the calculation of this numeric objective and its translation into nutrient concentrations. The fourth box from the left represents the calculation of a catchment nutrient load limit derived from the nutrient concentrations. The far right box represents the final step for policy-makers to translate the catchment load limit into land use restrictions.

Looking at the structure of the process, Figure 1 sets out a series of discrete steps. As a dissected virtuous cycle, each step is linked yet separated and is represented as occurring one after the other. Hence, Figure 1 represents the limit setting process as sequential and consequential. In terms of who is involved in each of these steps from beginning (left) to end (right), three phases are discernible with the community (boxes 1and 2) preceding the scientists (boxes 3 and 4), who precede the policy-makers (box 5). These boundaries were discursively reinforced. For example, in its commentary on how the limit setting regime should work, NIWA, a key LU\&WQP contributor, emphatically maintains that "difficult value judgments” have to be made by decision-makers (Norton et al. 2010: iv; Norton and Kelly 2010). It defines value judgments as "the decision that determines the desired balance between completing values. It sets the agreed level at which the individual values will be supported (i.e. it decides the desired environmental state ...” (Norton et al. 2010: vi). NIWA's statements delegate value judgments to the realm of policy, politics and negotiation. This "boundary defining language” (Jasanoff 1987: 195) seeks to ensure that science and scientists are not put at risk of becoming enmeshed in politics by being placed in the position of deciding (and potentially providing political cover) on where lines should be drawn in the balancing of social, ecological, cultural and economic sustainability well-beings (Norton and Kelly 2010; Norton et al. 2010). Notably, in the Hurunui Waiau zone, the decision-makers to which NIWA refers were the community stakeholder groups. 
This boundary ordering serves to uphold the legitimacy and credibility of science by distancing it from discussions and decisions about how the competing sustainability objectives should be reconciled at the front end of the process before science steps in. To further delineate value judgments from the science, NIWA goes on to say that "[t]hese value judgements are not technical decisions that are made by scientists ...” (Norton and Kelly 2010: 7). Statements such as these differentiate decision-maker judgments, which are deemed value-laden, as distinct from the judgments routinely made by scientists. Casting scientists' judgments, that inevitably reflect personal, cultural, disciplinary, methodological and/or institutional values (Wynne 1996), as merely technical decisions seeks to put them beyond questioning and uphold the objectivity of science. Overall, Figure 1 and the discursive boundary ordering demonstrates that New Zealand's limit setting regime is underpinned by the conventional linear knowledge governance model, and that the imperative to uphold epistemic authority is acute. I now turn to discussing the role of community stakeholder groups in the process and how their local knowledge was captured for conversion into nutrient limits.

\section{Eliciting community knowledge}

The community phase of the process was undertaken by the LU\&WQP over four workshops between July and October 2010. Stakeholder groups consisted of representatives from the indigenous community; multiple primary sectors and agribusiness; recreation, environmental, non-government, energy, tourism, community health, and rural women groups; local government and local community representatives, and representatives of a community-based zone committee established under the CWMS (Memon et al. 2012). The groups were asked to articulate their collective values by choosing and weighting no more than five values across the four sustainability well beings. The groups were provided with lists of potential values and indicators from which they could use, adapt or create their own. A chosen value 
equated to what each group considered to be important. The environmental/natural list included values such as 'soil health' and 'water quality for contact recreation'; the economic choices included potential values such as 'freedom to operate' and 'adequate access to water'; the cultural value choices included 'connectivity of the river system' and 'inclusion in decision making'; while the social options included 'well-maintained community facilities' and 'job satisfaction' (Wedderburn et al. 2011). Up to three indicators for each value had to be chosen. These values, weightings and indicators served as criteria to judge the acceptability or not of the identified impacts of future land and water use scenarios with which the groups were subsequently presented (Brown et al. 2011).

During the workshops, community group stakeholders had a chance to interact and exchange information, to learn from each other, understand varying perspectives and values, and to alter their values weightings in response to their deliberations. It was also at this point that they were able to interact with scientists and policy-makers. Both were present at the catchment workshops. Scientists presented their models and conclusions on impacts, they talked with stakeholders, responded to questions and comments and provided information as required (LU\&WQP no date; Wedderburn et al. 2011).

The scenarios the stakeholder groups were asked to consider represented different land use, water quality and economic development futures and their impacts that had been modelled and predicted by the LU\&WQP researchers. There were three scenarios. Scenario 1 represented the current state of the Hurunui catchment, from which two future land use scenarios were simulated. Scenario 2 represented business as usual and assumed land use intensification in line with historic trends. Scenario 3 represented extensive irrigation and assumed full irrigation on available land (Wedderburn et al. 2011: 10). The regional council and research institutions provided the stakeholder groups with briefings on the modelling and projected impacts across the economic, social, environmental and cultural well beings. The 
stakeholder groups then assessed the scenarios and their projected impacts against their criteria and associated indicators to determine what was and was not acceptable (Wedderburn et al. 2011). Group responses were made by the placement of a green, red or blue sticky dot to express, respectively, yes, no, don’t know.

The stakeholder groups were initially asked to choose between scenarios 2 and 3 . However, reportedly, due to different perceptions of the environmental risks involved in achieving these development-based scenarios (Brown et al. 2012: 17), a number of stakeholder groups requested the formulation of scenarios "driven by maintenance and enhancement of water quality” (Brown et al. 2011: 48). Consequently, two further scenarios were developed by the LU\&WQP. A conservative scenario A was modelled to identify what combination of land use would deliver the highest level of confidence of meeting water quality objectives This resulted in most land being turned to forestry. Scenario B was a combination of land use change and mitigation that aimed to achieve a state of water quality that existed in the catchment between 1990-1995. This scenario was expected to provide for some improvement on the current water quality situation but essentially it was translated as a decision to ensure that water quality remained at status quo levels (Memon et al. 2012).

In the end, according to the LU\&WQP, farmers, growers, agribusiness, rural women and health groups as well as the local council chose across scenarios B and 3 (that is extensive irrigation as well as an overall improvement in water quality) as the most acceptable, while environmental, tourism, energy and recreation groups chose scenarios across A and B (that is, a high level of certainty of achieving an overall improvement in water quality which implied a modest level of development) as the most acceptable. Notwithstanding the divergence in visions of economic futures, scenario B was taken by the LU\&WQP as the stakeholder groups' collective decision and was “translated into a management objective which articulates the desired resource state, namely, to maintain the current state of water quality in 
the main stem [of the Hurunui River] and improve some tributaries” (Brown et al. 2011: 48). It was then up to the LU\&WQP team to translate the intent of scenario B into a quantified nutrient load limit for the catchment that was expected to be used by the planners to restrict land use across the catchment (Norton and Kelly 2010: 6).

Clearly, the scenarios created by the LU\&WQP created difficult and irreconcilable choices for the stakeholder groups. It can also be seen that notwithstanding the stated intentions of the LU\&WQP to incorporate local knowledge, ultimately, only a fragment was elicited by the process and this was in terms of group values. Moreover, the process predominantly involved drawing responses to the scenarios, not the facilitation of the sharing of knowledges that would be expected from a commitment to embrace local knowledge.

\section{How far has conventional practice shifted?}

Having presented the empirical resources of this research and made comments on the way, I now return to my question, namely, how have shifts in governance that seek to incorporate local knowledge alongside scientific knowledge reshaped conventional science policy knowledge practice? I have argued that this is an important question to ask given two mediating factors. First, it is common practice in contentious natural resource decisionmaking for the knowledge claims of science, and the policy decisions represented as derived therefrom, to draw their legitimacy and credibility from a demarcation of science from the influence of politics and values. Second, a change in knowledge governance to embrace local knowledge is likely to be interpreted by scientists and policy-makers as undermining their mutually constituted epistemic authority with an injection of values where these have conventionally been deemed not to exist. So, what can this case study tell us about how far conventional science policy practice has shifted to accommodate local knowledge? I present two perspectives. 
If one subscribes to the linear model, Figure 1 depicts the conventional one-way flow of science into policy but with the community contribution preceding the science. It was during the second phase (box 2) that it could be argued that the process embodied the sustainability mandate reflected in commitments from the LU\&WQP to involve community stakeholders and utilise their local knowledge. Nestled within the knowledge-making process, it is here that community stakeholders interacted with each other, policy-makers and scientists. On this basis, it could be argued that conventional science policy knowledge practice has been shifted by the involvement of local knowledge and science has been forced to "share the stage with other kinds of knowledge” (Weber et al. 2010: 238). The interactions that took place during the workshops, and the rejection of the initial scenarios and calls for futures framed by water quality outcomes rather than economic development, illustrates the credence given to the local knowledge of the stakeholders.

On this basis, arguably, Figure 1 depicts a transformation of the conventional linear 'science in-policy out' model into a 'community/science in-policy out' knowledge governance framework. This is significant given that, notwithstanding the implicit power sharing that emboldens the legitimacy and credibility of science and policy, the routine retreat to science to defend policy decisions has become increasingly contested in New Zealand. Indeed, a major reason for the pursuit of a collaborative approach and the setting of environmental limits under the CWMS is that the regional council has been unable to successfully defend its science and predictive modelling in court to limit cumulative environmental effects (New Zealand Environment Court 2005; Weber et al. 2011; Russell et al. 2011). Similar moves to collaborative governance to avoid the gridlock of judicial remedies on water issues have occurred in the United States (Scholz and Stiftel 2005). It seems that drawing a line across the sustainability objectives has become so politically risky and contestable in the context of 
sustainability that neither scientists nor policy-makers are willing to mark it out (Sarewitz et al. 2000).

In the Hurunui Waiau zone, we saw the community stakeholder groups making the decisions on where to reconcile the sustainability objectives. Hence, the intercession of the stakeholder groups within the knowledge production process not only achieved the sustainability mandate to incorporate local knowledge, it also enlarged the scope for the endowment of epistemic authority for the policy decisions by virtue of it being provided by the community as well as the institution of science. On this basis, it could be argued that conventional science policy practice has been shifted and local knowledge has been embraced with the 'community/science in-policy out' framework delivering an additional pillar of credibility and legitimacy to the LU\&WQP outcomes and the overall limit setting regime.

\section{Looking beyond the demarcations}

The above account of the Hurunui Waiau zone limit setting process illustrates the epistemic implications of subscribing to the conventional linear knowledge governance model and the acceptance, at face value, of the boundaries marked out in Figure 1. In contrast, a constructivist epistemology takes as its ontology the inextricable interconnection of nature and culture (Jasanoff 2004; Latour 1993). As such, it looks beyond what are conceived as discursive demarcations that mark off science from policy, to reveal the values, politics and socio-cultural commitments that inescapably pervade and mutually constitute science policy relations (Irwin 2001; Jasanoff 2004; Wynne 1994). From a constructivist perspective, politics pervade science policy interactions. Fundamentally, the motivation to inoculate science from values and politics is not inscribed in nature but is in itself a political imperative (Gieryn 1983, 1999). It is doctrine that scientists and policy-makers substantiate the epistemic authority of their claims, which assumes permission to deploy political power 
(Irwin 2001; Jasanoff 1987, 1990, 2004; Gieryn 1983, 1999). The demarcations across Figure 1 and the discursive boundary ordering of NIWA illustrate this point.

From a constructivist perspective, community involvement in the Hurunui Waiau process served to consolidate the epistemic authority of scientists and policy-makers and constituted both as somehow detached from politics. This was possible given that the limit setting process was structured, and its implementation orchestrated, in such a way that local knowledge was slotted into the conventional sequence without hindering or threatening the political imperative for epistemic authority. Hence, notwithstanding the general agreement that adherence to the linear knowledge governance model is inadequate in the contemporary collaborative governance context (Folke et al. 2005; Pielke 2007; Scholtz and Stiftel 2005; Weber et al. 2010), the imperative to uphold scientific and political authority continues to anchor it steadfastly in place. On this basis, if community involvement follows the format seen in this case study, the sustainability mandate to open up knowledge-making to local knowledge is more likely to see the linear model entrenched rather than supplanted.

The politics that frame New Zealand's limit setting regime are also important to consider. It has strongly influenced how the process has been structured and how it has proceeded so far. For example, the calculation of limits required under the CWMS and the NPSFM takes as its point of departure not ecological capacity beyond which economic development can be pursued, but rather, somewhere in between. In other words, instead of first determining ecological capacity and then deciding how much agricultural expansion can occur within these ecological limits, the current regime requires the community to decide how much ecological protection it is (and is not) willing to trade off, and how much mitigation to pursue, to gain increased agricultural production, irrigation and economic development. The science and the predictive modelling would be vastly different if the politics mandated the establishment, first, of ecological capacity rather than the end point of nutrient limits. 
Nonetheless, the path everyone was sent down during the Hurunui Waiau limit setting process (and which continues in the Selwyn Waihora), was well past the point when the political decision was made at a national level that setting economically desirable quantified water quality limits was in the national interest (Board of Inquiry 2010; New Zealand National Party 2012; Office of the Minister for the Environment 2011). These politics permeate New Zealand's limit setting regime. In the Hurunui Waiau zone, they framed and constrained all phases from beginning to end and significantly restricted the elicitation of local knowledge, to which I now turn.

What were the implications of these politics, and the political imperative to engender epistemic authority, for opening up knowledge-making to local knowledge? The limit setting process was built around eliciting community stakeholder group statements about values in respect of sustainability objectives which equated to what was important. This is a far cry from taking on board knowledge "grounded in experiential and cultural understandings of problems” envisaged by Weber et al. (2010: 283). Instilled as a key phase in the knowledgemaking process, local knowledge had to be recognisable by and inputable to the ecosystem modelling. Hence, the elicitation of local knowledge within the limit setting process was structured in a manner conducive to deriving collatable, definitive answers that could be aggregated and translated into a discrete knowledge input. Narratives, experiences, histories and recollections did not fit this mould. Nor did expressions of distrust, sadness, disbelief, confusion, outrage or invalidation of social identity (Wynne 1996, 2001).

The values of the institution of science that are deemed essential to endow epistemic authority are embodied in its methods that aggregate, categorise and standardize. These normalised and depoliticised means, that fit so comfortably with policy and political ends, were applied to the community stakeholder groups, their local knowledge and their values. In the act of participants choosing a sticky dot - wholeheartedly, tentatively or not - their 
responses were stripped of their complexity, contingency and ambivalence. As such, they were reified as universal and static along with the numeric objective, the nutrient concentrations and the ultimate nutrient load limit, all of which were extrapolated from the high frequency of scenario B in the relatively small sample. On this basis, conventional science policy practice did not embrace local knowledge. Rather, it reformatted and recalibrated it to operationalise political means (i.e. a quantified nutrient limit setting regime) and to achieve political ends (i.e. the attainment of economic growth via the intensification of agriculture).

\section{Conclusions}

A contrast of the two perspectives - from a commitment to the linear model and its critique from a contructivist perspective - illustrated the extent to which the former constitutes knowledge as merely instrumental. As such, it belies a far more complicated and intertwined relationship between nature, science and politics. A focus on how conventional science policy practice has been shifted in response to the sustainability mandate to embrace local knowledge has highlighted the extent to which the pursuit of epistemic authority is enculturated, deep-seated and mutually constituted across the domains of science and policy. In the Hurunui Waiau zone, this political imperative had profound implications for how local knowledge was converted into nutrient limits. The community phase, upon which all others depended, was slotted in before the science. We saw examples of the discursive boundary ordering by scientists to cordon off the community value judgments from the objectivity of the science. This placement of local knowledge, while appearing perfectly sensible, served multiple political purposes. First, it provided political cover for policy-makers who were able to abrogate contentious decision-making onto the community. The argument here is not that the community should not be making these decisions but how they have been permitted to do so. Second, this placement also provided political cover for the scientists who are clearly 
unwilling to become complicit in contentious debates that have the potential to undermine their epistemic authority. The involvement of the community consolidated the epistemic authority of both science and policy. As such, the mandate to involve local knowledge, in this case, served to anchor an adherence to the linear model firmly in place.

The political imperative to uphold epistemic authority also had implications for how the community and its local knowledge was involved in this knowledge-making process. We saw that only a fragment of local knowledge was deemed valid and reliable by virtue of the elicitation of values and the presence of a 'sticky dot'. Values, defined in terms of what was important, was all that was required and only to the extent that they could be aggregated and modelled. To be accepted as legitimate, the expression of local knowledge had to align with the mutually constituted socio-cultural values of science and policy that were framed by the objective to calculate politically palatable and economically viable quantified nutrient limits. Therefore, local knowledge had to be extracted and thereby expressed by participants in a manner that allowed its requisite aggregation, first as stakeholder groups and then as a collective jurisdictional zone of the Hurunui Waiau. This recalibration, aggregation and standardization stripped local knowledge of its complexity, contingency and ambivalence. An important focus for further research is how stakeholders encountered and negotiated these scientific and political framings and commitments that obliged them to make statements that constituted the expression of their values as an endorsement and an acceptance of the depoliticisation of the politics of New Zealand's limit setting regime. 
References:

Board of Inquiry. 2010. Board of Inquiry: Proposed National Policy Statement for Freshwater Management. Report and Recommendations of the Board of Inquiry into the Proposed National Policy Statement for Freshwater Management. http://www.mfe.govt.nz/rma/central/nps/consultation/index.html (accessed 25 August 2012).

Brown, I., N. Norton, L. Wedderburn, R. Monaghan, S. Harris, S. Hayward and R. Ford. 2011. Nutrient Management in Hurunui: A Case Study in Identifying Options and Opportunities. Available at http://ecan.govt.nz/publications/Reports/nutrient-managementhurunui-case-study-identifying-options-opportunities-001111.pdf

Cash, David H., Jonathan C. Borck, and Anthony G. Patt. 2006. "Countering the LoadingDock Approach to Linking Science and Decision Making: Comparative Analysis of El Nino/Southern Oscillation (ENSO) Forecasting Systems.” Science, Technology \& Human Values 31 (4): 465-94.

CWMS (Canterbury Water Management Strategy). 2010. Strategic Framework 2009 Targets updated July 2010. Available from http://ecan.govt.nz/get-involved/canterburywater/Pages/Default.aspx

ECRC (Environment Canterbury Regional Council). nd. Land Use and Water Quality Project, Frequently Asked Questions. Available at: http://ecan.govt.nz/publications/General/land-use-water-quality-project-faq-13-july-2010.pdf (accessed 25 April 2012).

ECRC (Environment Canterbury Regional Council). 2012. The preferred approach for managing the cumulative effects of land use on water quality in the Canterbury Region: a working paper. Christchurch: Environment Canterbury. Available from http://ecan.govt.nz/publications/Reports/luwq-preferred-approach-report-jan2012.pdf

Folke, C., Hahn, T., Olsson, P and J. Norberg. 2005. "Adaptive Governance of SocialEcological Systems.” Annual Review of Environment and Resources. 30:441-73

Gieryn, Thomas F. 1983. "Boundary-work and the demarcation of science from non-science: strains and interests in professional ideologies of scientists.” American Sociological Review 48: 781-795.

Gieryn, Thomas. F. 1999. Cultural Boundaries of Science: Credibility on the Line. Chicago: The University of Chicago Press.

Guston, David. H. 2001. "Boundary organizations in environmental policy and science: An introduction.” Science, Technology \& Human Values. 26(4): 399-408. 
Irwin, Alan and Brian Wynne. (1996) “Introduction” Pp. 1-17 in Misunderstanding Science? The Public Reconstruction of Science and Technology, -- eds Alan Irwin and Brian Wynne. Cambridge: Cambridge University Press.

Irwin, Alan. 2001. Sociology and the Environment: A Critical Introduction to Society, Nature and Knowledge. Cambridge: Polity Press.

Jasanoff, Sheila. 1987. “Contested Boundaries in Policy-Relevant Science.” Social Studies of Science 17: 195-230.

Jasanoff, Sheila. 1990. The Fifth Branch: Science Advisers as Policymakers Cambridge, MA: Harvard University Press.

Jasanoff, Sheila. 2004. “Ordering knowledge, ordering society”, Pp. 13-45 in States of Knowledge: the Co-production of Science and Social Order, --ed Sheila Jasanoff, London: Routledge.

Land and Water Forum. 2010. Report of the Land and Water Forum: A Fresh Start for Freshwater. http://www.landandwater.org.nz/

Land and Water Forum. 2012. Second Report of the Land and Water Forum: Setting Limits for Water Quality and Quantity Freshwater Policy- and Plan-Making Through Collaboration.

http://www.landandwater.org.nz/

LU\&WQP (Land Use and Water Quality Project). no date. Land Use and Water Quality http://ecan.govt.nz/get-involved/water-projects/land-use-and-water-quality/pages/default.aspx (accessed 25 April 2012).

Landstrom, C., S.J. Whatmore, S.N. Lane, N.A. Odoni, N. Ward, and S. Bradley. 2011. "Coproducing flood risk knowledge: redistributing expertise in critical 'participatory modelling’.” Environment and Planning A 43, 1617-1633.

Lane, S.N., N. Odoni, C. Landstrom, S.J. Whatmore, N. Ward and S. Bradley. 2011. "Doing flood risk science differently: an experiment in radical scientific method." Transactions of the Institute of British Geographers 36: 15-36.

Latour, Bruno 1993. We Have Never Been Modern. Translated by Catherine Porter. Cambridge, MA: Harvard University Press.

Latour, Bruno 2004. Politics of Nature: How to Bring the Sciences into Democracy. Translated by Catherine Porter. Cambridge, MA: Harvard University Press,

MfE (Ministry for the Environment). 2011a. Nitrogen in rivers - national network http://www.mfe.govt.nz/environmental-reporting/freshwater/river/nutrients/nitrate/nationalnetwork.html (accessed 25 April 2012).

MfE (Ministry for the Environment). 2011b. National Policy Statement for Freshwater Management 2011. Available from http://www.mfe.govt.nz/rma/central/nps/freshwatermanagement.html 
MfE (Ministry for the Environment). 2011c. National Policy Statement for Freshwater Management 2011: Implementation Guide. Wellington: New Zealand Government. Available from http://www.mfe.govt.nz/rma/central/nps/freshwater-management.html

MAF (Ministry of Agriculture and Forestry). 2011. International Trade: Agricultural and forestry exports from New Zealand. www.maf.govt.nz/agriculture/statisticsforecasting/international-trade.aspx (accessed 20 April 2012).

Memon, Ali, Ronlyn Duncan and Anne Spicer. 2012. The Hurunui Waiau Zone Implementation Programme as a Collaborative Planning Process: A Preliminary Review. Christchurch: Environment Canterbury Regional Council. Available from http://ecan.govt.nz/publications/Reports/hurunui-waiau-zip-collaborative-planningprocess.pdf

New Zealand Environment Court, 2005. Lynton Dairy Limited and The Canterbury Regional Council, decision C108/2005.

New Zealand National Party 2012. Building a Bluegreen Future: An environmental policy paper by the New Zealand National Party. Available from www.national.org.au

Norton, Ned and David Kelly. 2010. Current nutrient loads and options for nutrient load limits for a case study catchment: Hurunui catchment. Report prepared for Environment Canterbury. Christchurch: NIWA.

Norton, Ned, Ton Snelder and Helen Rouse. 2010. Technical and Scientific Considerations When Setting Measurable Objectives and Limits for Water Management. Prepared for Ministry for the Environment. Christchurch: National Institute of Water \& Atmospheric Research Ltd (NIWA).

Office of the Minister for the Environment. 2011. New Zealand Government Cabinet Paper titled National Policy Statement for Freshwater Management presented by Hon. Dr. Nick Smith, 4 May 2011. Wellington: New Zealand Government. http://www.mfe.govt.nz/cabinet-papers/freshwaternps.pdf (accessed 25 July 2012).

Pielke, Roger A. 2007. The Honest Broker: Making Sense of Science and Policy and Politics. Cambridge: Cambridge University Press.

PCE (Parliamentary Commissioner for the Environment). 2012. Water quality in New Zealand: Understanding the Science. Wellington: PCE. Available at www.pce.parliament.nz

Russell, Shona, Bob Frame, and James Lennox eds. 2011. Old Problems New Solutions: Integrative research supporting natural resource governance. Lincoln, NZ: Landcare Research.

Sarewitz, Daniel, Roger A. Pielke, Jr., and Radford Byerly, Jr. eds. 2000. Prediction: Science, Decision Making and the Future of Nature. Washington: Island Press. 
Scholz, John T., and Bruce Stiftel, eds. 2005. Adaptive Governance and Water Conflict: New Institutions for Collaborative Planning. Washington: Resources for the Future.

Voinov, Alexey, and Francois Bousquet. 2010. "Modelling with stakeholders." Environmental Modelling \& Software 25: 1268-1281.

Wallington, Tabatha, Kirsten Maclean, Toni Darbas and Cathy J. Robinson. 2010. "Knowledge-Action Systems for Integrated Water Management: National and International Experiences, and Implications for South East Queensland.” Urban Water Security Research Alliance Technical Report No. 29.

Weber, Edward, P., Thomas M. Leschine and Jon Brock. 2010. "Civic Science and Salmon Recovery Planning in Puget Sound.” Policy Studies Journal 38 (2): 235-256.

Weber, Edward P., Ali Memon and Brett Painter. 2011. "Science, Society, and Water Resources in New Zealand: Recognizing and Overcoming a Societal Impasse.” Journal of Environmental Policy \& Planning 13 (1): 46-69.

Wedderburn, Liz, Denise Bewsell, Paula Blackett, Margaret Brown, Steven Kelly, Michael Mackay, Kambiz Maani, Oscar Montes and Tracy Payne. 2011. Developing a Preferred Aproach for Managing the Cumulative Effets of Land Uses on Freshwater Quality: Report prepared for P21 Environment Programme and Environment Canterbury. Christchurch: AgResearch.

Whatmore, Sarah J. 2009. "Mapping knowledge controversies: science, democracy and the redistribution of expertise.” Progress in Human Geography 33 (5): 587-598.

Whitehouse, Ian. 2010. Canterbury Water Management Strategy Hurunui - Waiau Zone Committee and LUWQ Project. Christchurch: Environment Canterbury. Available from http://ecan.govt.nz/get-involved/water-projects/land-use-and-water-quality/pages/default.aspx Accessed 7 April 2012.

Wynne, Brian. 1994. "Scientific Knowledge and the Global Environment.” Pp. 169-89 in Social Theory and the Global Environment,

-- eds Michael Redclift and Tom Benton, London: Routledge.

Wynne, Brian. 1996. "Misunderstood misunderstandings: social identities and public uptake of science.” Pp. 19-46 in Misundersanding science? The public reconstruction of science and technology,

--eds Alan Irwin and Brian Wynne, Cambridge: Cambridge University Press.

Wynne, Brian. 2001. "Creating Public Alienation: Expert Cultures of Risk and Ethics on GMOs.” Science as Culture. 10(4):445-481. 
